J urral PenddkanBałesacknSastra V dume12, Nomr 2, Oktdber 2012

\title{
VISI-VISI POSTMODERN DALAM KESUSASTRAAN JERMAN AWAL ABAD KE-20
}

\author{
Dudy Syafruddin \\ FBS, Universitas Negeri Malang \\ Korespondensi: Jl. Semaran No.5 Malang 65145 Telp. (0341) 551312
}

\begin{abstract}
Abstrak
Visi-Visi PostModem dalam Kesusastraan Jeman Awal Abad ke-20. Aliran pemikiran postmodern yang menyeruak di segala bidang kehidupan mulai dirasakan pada paruh kedua abad ke-20. Namun akar pemikiran tersebut sudah mulai tampak pada abad ke-19. Kritik terhadap pemikiran modern itu muncul dalam berbagai ekspresi masyarakat, seperti seni, arsitektur, dan sastra. Dalam kesusastraan Jerman pemikiran yang dapat dikategorikan sebagai visi postmodern dapat kita temukan dalam beberapa karya sastranya yang terbit pada awal abad ke-20. Tulisan ini membahas tentang visi-visi postmodern yang terdapat dalam novel Siddahartha karya Hermann Hesse yang ditulis pada tahun 1919. Pembahasan difokuskan kepada visi spiritualitas postmoden. Visi-visi spiritualitas tersebut muncul dalam gambaran tentang tokoh utamanya dan relasi antar tokoh serta latarnya. Spiritualitas yang bersifat internal, esensial, dan konstitutif serta spiritualitas yang bersifat organis hadir menjadi penawar permasalahan modernism pada masa karya tersebut ditulis.
\end{abstract}

Kata kunci: Postmodern, Siddhartha, spiritualitas

\begin{abstract}
Postmodem Visions In Geman Literature In The Beginning Of 20th Century. The flow of postmodern thinking in all areas of life began to imerge in the second half of the 20th century However; the roots of these ideas already started to appear in the 19th century. Criticism towards modern thinking occured in various expressions of the society, such as art, architecture, and literature. In G erman literature, ideas that can be categorized as postmodern vision can be found in several literary works published in the early 20th century. This paper discusses the postmodern visions contained in the novel Siddhartha written by Hermann Hesse in 1919. The discussion in this paper focuses on the vision of postmodern spirituality. The spiritual visions appear in the description of the main character and intercharacter relationships, and background. Spirituality which is internal, essential, and constitutive, and spirituality that is organis comes to netralize the issue of modernism at the time the work was written.
\end{abstract}

Keywords: postmodern, Siddhartha, spirituality 